\title{
Conditions for Securitization of International Terrorism in Central Asia
}

\section{Irina Chernykh and Rustam Burnashev*}

One trend that has gained particular prominence in current discourse on international relations is the increasingly active role of non-state actors. It has been asserted that these actors' spheres of operation are gradually shifting from the domestic and regional to the global level. Their actions are becoming sufficiently large in scope to transform the dynamics within a region and to change relations among regions and great powers, as well as relations among the great powers themselves. Thus, much current debate is directed at the role of non-state actors in international relations. After the events of September 11, 2001, special attention has been given in this discourse to one type of non-state actor in particular: international terrorism. ${ }^{1}$

A crucial step in the study of international terrorism is clarifying the terms in which it is formulated and defined in current debate within the field of international relations. From our vantage point, any analysis of these conditions must focus primarily on the regional level, which avoids making the problem overly universal and allows us to distinguish between the specific features of various regional contexts. In this article, we will analyze the conditions that have shaped a specific regional discourse, giving particular attention to international terrorism and using Central Asia as an example. We have chosen this region for two reasons. First, having been essentially on the periphery of much of present-day international relations, Central Asia has been drawn directly into the fight against international terrorism because of Operation Enduring Freedom in Afghanistan. A second reason is that the actions of Central Asian countries are a demonstration of securitization in formulating approaches to international counterterrorism. $^{2}$

* This article was written with support from the CARI HESP OSI Program (Budapest). Irina Chernykh and Rustam Burnashev are professors at the Kazakhstan-German University. Translated from the Russian by Language Services Branch, George C. Marshall Center.

1 Of course, the assertion that the starting point for "international" terrorism was September 11,2001 is not fully correct. For example, "the first item on the agenda of the first meeting of the National Security Council under President Reagan was international terrorism.... Secretary of State Alexander Haig announced ... that 'international terrorism will take the place of human rights' as the number one priority of the Reagan administration. A decade later George Bush ... proclaimed in his Inaugural Address that terrorism and drugs would be the two primary targets of his administration." James Der Derian, Antidiplomacy: Spies, Terror, Speed, and War (Oxford: Blackwell Publishers, 1992), 73.

2 Buzan and Wæver define securitization as "the discursive process through which an intersubjective understanding is constructed within a political community to treat something as an existential threat to a valued referent object, and to enable a call for urgent and exceptional measures to deal with the threat." Barry Buzan and Ole Wæver, Regions and Powers: The Structure of International Security (Cambridge: Cambridge University Press, 2003), 491. 
Of course, the regional approach does not fit all cases, and would be insufficient to analyze the position of the United States, for example, which is a world power. This approach is also limited to the subject at hand - non-state actors in international relations. By definition, such actors cannot be characterized in territorial terms, and in the modern system of international relations they have the opportunity to be active and circumvent the limitations imposed by national borders; they may also join forces, forming networks that can affect national, regional, and even global security dynamics. For example, although the objectives and motives of the Islamic Movement of Uzbekistan (Islamic Movement of Turkistan) and the Uighur separatists in China are expressly domestic in nature, these movements are transnational and cannot be understood without reference both to regional security structures and to their interaction at the inter-regional and global levels. Therefore, the analytical underpinning of this article is regional security complex theory, which may be viewed as a matrix for regional studies and provides the opportunity to link the study of the situation within countries in the complex under investigation to relations among states and other international relations actors in this range, as well as to the types of interaction between this complex and neighboring ones and with the world powers. ${ }^{3}$ The analysis will be structured according to these four levels. The key concepts in this theory are securitization and the regional security complex. ${ }^{4}$ The concepts of mini-complex, ${ }^{5}$ unstructured security region, ${ }^{6}$ and insula$\operatorname{tor}^{7}$ are also important for this study.

A number of authors have applied regional security complex theory to the study of security dynamics in Central Asia. However, in most cases Central Asia is viewed either as an independent regional security complex, or as an integral part (sub-complex)

3 For more on regional security complex theory, see: Barry Buzan, People, States and Fear: An Agenda for International Security Studies in the Post-Could War Era, 2nd ed. (Hemel Hempstead: Harvester Wheatsheaf, 1991); Barry Buzan, Ole Wæver, and Jaap de Wilde, Security: A New Framework for Analysis (Boulder, CO: Lynne Rienner, 1998); and Buzan and Wæver, Regions and Powers.

4 "Regional security complex - a set of units whose major processes of securitization, desecuritization, or both are so interlinked that their security problems cannot reasonably be analysed or resolved apart from one another." Buzan and Wæver, Regions and Powers, 491; see also Buzan, et al., Security, 204.

5 "Mini-complex - a formation with the characteristics of a security complex, but small in scale and usually composed at least in part of substate actors." Buzan and Wæver, Regions and Powers, 490.

6 "Unstructured security region - where local states are so weak that their power does not project much, if at all, beyond their own boundaries, and so generate insufficient security interdependence to form the essential structures of a regional security complex." Buzan and Wæver, Regions and Powers, 492.

7 "Insulator - a state or mini-complex standing between regional security complexes and defining a location where larger regional security dynamics stand back to back." Buzan and Wæver, Regions and Powers, 490. 
of the regional security complex that has Russia at its core. ${ }^{8}$ It seems to us that this fails to fully convey the specific nature of the security environment in and around Central Asia, since Central Asia is more likely an unstructured security region and a minicomplex that serves as an insulator between East Asian, South Asian, and Middle Eastern regional security complexes and the security complex that Russia is attempting to build around itself. This approach explains the conditions for securitizing the struggle against international terrorism in Central Asia.

The research technique used in this work is Michel Foucault's "archeological" approach, in a form reconstructed by Hubert Dreyfus and Paul Rabinow. ${ }^{9}$ According to this methodology, research should begin with a diagnosis of a given problem. Having identified the problem, the analyst considers the conditions (background practices) that made it possible to formulate and articulate the problem in discourse. The set of practices that create the background of a given discourse determine its four main characteristics:

1. What kind of phenomena may become the object of the discourse;

2. Who may assume the position of speaking subject;

3. What kinds of concepts may be acceptable in this discourse;

4. What theories may be pondered and formulated in the discourse. ${ }^{10}$

8 For the former approach, see Bruno Coppieters, "The Partnership for Peace with Central Asia," in Ethnic and Regional Conflicts in Eurasia, vol. 3: International Experience of Resolving Ethnic Conflicts, ed. Bruno Coppieters, Eric Remacle, and Aleksei Zverev (Moscow, Ves' mir, 1997); Hooman Peimani, Regional Security and the Future of Central Asia (Westport, CT: Praeger, 1998); Lena Jonson and Roy Allison, "Central Asian Security: Internal and External Dynamics," in Central Asian Security: The New International Context, ed. Lena Jonson and Roy Allison (Washington, D.C.: Brookings Institution Press/ London: Royal Institute of International Affairs, 2001); and Rustam Burnashev, "Regional Security in Central Asia: Military Aspects," in Central Asia: A Gathering Storm?, ed. Boris Rumer (New York: M. E. Sharpe, 2002. For the approach that views Central Asia as being part of a Russocentric regional security complex, see Philip G. Roeder, "From Hierarchy to Hegemony: The Post-Soviet Security Complex," in Regional Orders: Building Security in a New World, ed. David A. Lake and Patrick M. Morgan (University Park, PA: The Pennsylvania State University Press); and Buzan and Wæver, Regions and Powers.

9 Michel Foucault outlined this approach in a series of landmark works that include: Folie et deraison. Histoire de la foile a l'age classiqu (Paris: Plon, 1961); Naissance de la clinique (Paris: P.U.F., 1963); Les mots et les choses (Paris: Gallimard, 1966); and, most notably, L'archeologie du savoir (Paris: Gallimard, 1969). The refinement of the technique that we are using draws on Hubert L. Dreyfus and Paul Rabinow, Michel Foucault. Beyond Structuralism and Hermeneutics, 2nd ed. (Chicago: University of Chicago Press, 1983); see also Oleg Kharkhordin, "Foucault and the Study of Background Practices," in Michel Foucault and Russia, ed. Oleg Kharkhordin (Saint Petersburg: European University at Saint Petersburg/Moscow: Summer Garden, 2001), 51, 52.

${ }^{10}$ Kharkhordin, "Foucault and the Study of Background Practices," 52. 
Ole Wæver uses a similar method of analysis to study integration structures in Europe. ${ }^{11}$ Due to this article's limited scope, it will mainly present our findings based on this methodology rather than the procedure of the analysis itself.

\section{Domestic Level}

An understanding of the situation within the countries of a regional security complex is built primarily by dividing the countries into two groups: "powerful" and "weak." The spectrum of weak and powerful nations is determined by: ${ }^{12}$

- The degree of social and political unity between civil society and government institutions;

- The degree to which the state corresponds to the nation;

- The degree of statehood possessed by the country and the degree of stability in terms of internal order.

The type of state dominant in the region has tremendous influence on the dynamics of regional stability.

Central Asian states are weak, although not to an equal degree. One may generalize by saying that, to a varying extent, states in the region are typified by a low level of social and political cohesion and a narrow social base of support for existing political regimes (particularly among the "middle" class). This is less true for Kazakhstan, where the vast majority of the population is politically apathetic. Identification along ethnic lines is weak here, and is forced to compete with other forms of self-identity. Despite a well-developed state repressive machine (particularly in Uzbekistan and Turkmenistan), Central Asian countries are all experiencing one drawback of statehood: their governmental and national bodies are self-sufficient, and serve more as forums in which sub-state actors compete among themselves to ensure their own security and/or to exert influence over the country.

The civil war in Tajikistan is the most revealing window to understand security dynamics in the states of Central Asia. This war graphically illustrated how a country's weakness may result in the failure of statehood, and ultimately in national disintegration. Competition between different forms of identity politics (religious, ethnic, subethnic, and clan-based) and their corresponding elites' struggle for power played an enormous role in sparking the civil war. The conflict was managed by balancing the interests of the opposing elites, with mediation by and under the influence of external

11 Ole Wæver, "Identity, Communities and Foreign Policy: Discourse Analysis as Foreign Policy Theory," in European Integration and National Identity: The Challenge of the Nordic States, ed. Lene Hansen and Ole Wæver (London: Routledge, 2002); and Wæver, European Integration and Security: Analysing French and German Discourses on State, Nation and Europe, 2003, available at: www/polsci.ku.dk/courses/gamle_fag/Efteraar2002/ Begreb_om_sikkerhed/European integration and security Feb 2003.doc.

12 Buzan, People. States, and Fear, 96-107. 
forces - including Russia, Iran, and Uzbekistan - and was shaped by events in Afghanistan, particularly the success of the Taliban movement in the autumn of 1996.

The weakness of one Central Asian country can be securitized not only by the elites of that country, but by those of neighboring countries as well (although the experience of the civil war in Tajikistan demonstrated a trend toward localizing combat activities within a single country, despite the fact that elements of irredentism and separatism were present in that conflict). For instance, the failure to effect economic and political reform in Uzbekistan was justified by the example of the war in Tajikistan, which was juxtaposed to the "calm and order" in Uzbekistan. Kazakh analysts regard the possibility of political destabilization in Uzbekistan as a major threat to their country.

All other things being equal, weak states and their ruling elites are more inclined toward securitization. For example, the weakness of Central Asian states leads to securitization when dealing with such issues as migration, the drug trade, religious extremism, and international terrorism. ${ }^{13}$ This tendency toward securitization is largely driven by the fact that, when speaking about the security and stability of their country, the ruling elites equate themselves with the nation. The governments of Central Asian states are convinced that security and stability are to be prized above all other values. This is most vividly manifested in Uzbekistan, where any decision on economic and political reforms is viewed through the lens of whether or not they will help to maintain "order" in the country and keep the ruling elite in power. The argument is built on the premise that endowing the citizens with political rights would be too risky in light of the complexity of the external security situation. In this sense, securitizing "Islamic fundamentalism" and "international terrorism" plays into the hands of the ruling elites of Central Asian countries. The ruling regimes attempt to portray any manifestations of extremism in Central Asian countries as being international in nature.

\section{The Regional Level}

The regional level is defined by the degree to which countries making up the regional complex securitize one another's actions and by the degree to which one country perceives another to be a threat to its security. Emerging securitization relationships determine the essential structure of a regional security complex: the internal structure (polarity, which describes the distribution of power among the units, and social construction, which includes the patterns of amity and enmity among the units) and the external boundaries of the regional security complex. ${ }^{14}$ In analyzing the security situation in Central Asia, it is impossible to clearly identify either the internal structure or the external boundaries of the regional security complex. Central Asia is considered to include Kazakhstan, Kyrgyzstan, Tajikistan, Turkmenistan, and Uzbekistan, but this is

13 This is particularly typical of the works of political leaders in the Central Asian states, e.g. Nursultan Nazarbaev, The Critical Decade (Almaty: Atamura, 2003); or Islam Karimov, Uzbekistan on the Threshold of the XXI Century: Security Threats, Conditions and Guarantees of Progress (Tashkent: Uzbekistan, 1997).

14 Buzan and Wæver, Regions and Powers, 53. 
more a political convention than a reflection of any structural links that exist between these five countries and their neighbors. ${ }^{15}$

\section{Internal Structures}

By definition, in a regional security complex internal forms of interaction should be more important to the complex and its entities than external ones. It is typical for Central Asian countries to have looser ties among themselves than they have in their relationships with neighboring countries. Countries of the Central Asian mini-complex do not securitize one another, and accordingly do not ally against one another. The degree to which Central Asian countries' relations with Russia and China (for Kazakhstan and Kyrgyzstan) or Afghanistan (for Uzbekistan and Tajikistan) have been securitized was and is much greater. The stance of Turkmenistan, which is distancing itself from any processes in Central Asia, is very indicative of the weakness of interstate dynamics. Regional security initiatives, as a rule, remain unfulfilled (e.g., creation of a "Centrasbat"), ${ }^{16}$ or are ineffective (e.g., the Central Asian Union). ${ }^{17}$ Also obvious is the widely varying degree to which Central Asian countries securitize the same issues - for example, China or Afghanistan's influence on Central Asia, the opposition's role, or the activities of international organizations.

There is some similarity in the positions of Central Asian countries with respect to certain transnational and sub-state actors (particularly terrorist and religious groups) whose activities are perceived as being international in nature, and there is a tendency toward greater securitization of actions taken against these actors. ${ }^{18}$ The dynamics of change in the content of treaties and agreements signed by Central Asian countries is quite revealing in this regard. While security arrangements adopted in Central Asia

${ }^{15}$ See Burnashev, "Regional Security in Central Asia," 139-41, for more detail on the impossibility of determining the internal structure and delineating the external boundaries of Central Asia as a region.

16 The decision to establish the "Centrasbat" peacekeeping battalion was made in 1995 . Centrasbat is a battalion consisting of 500 Uzbek, Kazakh, and Kyrgyz troops and tasked to carry out operations under the aegis of the UN. It was to be trained under NATO's Partnership for Peace program. However, this intent was not fully realized, and the Centrasbat disintegrated into national peacekeeping units. See Rustam Burnashev, "The Dynamics of NATO Presence in Central Asia: An Analysis Based on the Theory of Regional Security Complexes," in The U.S. and Central Asia: The Realities and Future of Cooperation (Almaty: Kazakh al Farabi Central University, 2004).

17 The Central Asian Union was created in 1994 by Kazakhstan, Kyrgyzstan, and Uzbekistan. Tajikistan joined in 1998, and Russia in 2004. The Union's requirements were repeatedly violated by the institution of protectionist measures by member states. The name of the organization has changed.

Officials in Central Asian states interpret any terrorist act as a manifestation of international terrorism. See, for example, the statement by the press secretary for Uzbekistan's foreign minister, Ilkhom Zakirov, on the terrorist acts in Tashkent and Bukhara committed on 28 and 29 March 2004 (RIA Novosti, 29 March 2004): "In this act one can see the continuation of events in Madrid and events taking place now in the south of Afghanistan." 
from 1997-1998 (the Treaty of Eternal Friendship between Kazakhstan, Uzbekistan, and Kyrgyzstan, and the Joint Statement by Kazakhstan, Kyrgyzstan, Tajikistan, and Uzbekistan on Measures to Establish a Regional Security System in Central Asia) were aimed at regulating interstate relations, documents signed in 1999 and later (for example, the 2000 Treaty between Kazakhstan, Kyrgyzstan, Tajikistan, and Uzbekistan on Joint Actions in the Fight Against Terrorism, Political and Religious Extremism, Transnational Organized Crime, and Other Threats to Stability and Security) focus on "new dimensions of international security," such as migration, demographic problems, trafficking in drugs and arms, transnational organized crime, and terrorism. ${ }^{19}$

Thus, since cooperation among Central Asian states is mainly focused not on relations within the mini-complex, but on addressing external challenges (perceived as threats), one can assert that patterns of amity and enmity among Central Asian countries have not yet taken shape. Relations that could be described as patterns of amity and enmity are not interstate in nature, but instead are being formed at the sub-state level: between ethnic groups, industrial and financial elites, and so forth. For this very reason one can agree with Lena Jonson and Roy Allison that the concepts of "amity" and "enmity" are overstated for the Central Asian context, and might be replaced by "friendship" and "suspicion." ${ }^{20}$ For example, similar relations are manifested between sub-state actors connected to Uzbekistan and Tajikistan. Those relationships have deep historical roots and are expressed both in fairly aggressive rhetoric and mutual accusations, and in indirectly hostile actions (indirect support by some Uzbekistan elites and officials for the M. Khodabardiyev rebellion in Khudzhande in November 1998, and the Tajikistan government's support of units of the Islamic Movement of Uzbekistan in 1999 and 2000). However, these relations are unlikely to become interstate in nature.

\section{External Borders}

When defining "external borders," the following actors play a special role with respect to Central Asia:

- Russia, striving to form around itself a regional security complex that includes, among other entities, Central Asia (or individual countries from that mini-complex, primarily Kazakhstan).

- Afghanistan, which is an insulator between the East Asian and South Asian regional security complexes and Russia and Central Asia. Analysts and some political leaders are discussing the possibility of Central Asia (or individual countries in the complex, primarily Uzbekistan and Tajikistan) joining with Afghanistan to form a new regional entity. ${ }^{21}$

19 A similar trend can be seen in the change in national security policy documents. Prior to 1999 , the possibility of foreign aggression was securitized; now the focus is on such issues as migration, drugs, crime, and terrorism. See, for example, Military Doctrine of the Republic of Kazakhstan (2000) or the Defense Doctrine of the Republic of Uzbekistan (2000).

20 Jonson and Allison, "Central Asian Security," 8.

21 In December 2002, Afghanistan was invited to join the Central Asian Union as an observer. 
- The Caucasus mini-complex/unstructured security region, which includes Azerbaijan, and which - along with some Central Asian countries (Kazakhstan and Turkmenistan), Russia, and Iran-forms the Caspian mini-complex. The Caspian mini-complex links Central Asia and the Caucasus, offering an alternative security unit.

The absence of internal structures and the weakness of interstate relations in Central Asia dictate the weakness of such regional entities as the Central Asian Union, as well as the absence of regional structures and security regimes.

\section{The Inter-Regional Level}

The inter-regional level of security is constituted of interactions between Central Asia and neighboring regional security complexes. At this level are the East Asian, South Asian, and Middle Eastern regional security complexes (including some regional powers belonging to those complexes); Turkey; and Afghanistan, which is regarded as an insulator.

China, Pakistan, Iran, and Turkey (and, to a lesser degree, Korea and Japan) account for the interaction, primarily on the national level, between the East Asian, South Asian, and Middle Eastern regional security complexes and Central Asia. All these regional security complexes and associated forces have their own internal dynamics, which are of more immediate importance to them than those of Central Asia. After the breakup of the Soviet Union and the "discovery" of Central Asia, it was expected that Central Asia would become the arena for a new "great game" involving a variety of inter-regional actors vying for influence. However, these actors displayed an unexpectedly low level of interest in Central Asia.

Afghanistan is of crucial importance in understanding the conditions under which international terrorism is securitized in Central Asia at the inter-regional level. The forms of security dynamics in Afghanistan and Central Asia are closely interrelated, and some countries in the mini-complex are strongly influenced by dynamics within Afghanistan. Moreover, most ties are determined by the weakness of Central Asian countries and the fragmentation of Afghanistan; these links are established through sub-state and transnational actors, such as criminal syndicates associated with drug trafficking, ethnic and sub-ethnic groups, guerrilla and gang-related groups, and religious movements. ${ }^{22}$ The fragmentation of Afghanistan has allowed Central Asian governments to draw connections between the disintegrating state and the activities of terrorist and extremist groups, thereby lending those groups a more international flavor (e.g., the Islamic Movement of Uzbekistan). It has been pointed out, for example, that

${ }^{22}$ See Ahmed Rashid, Taliban: Islam, Oil and the New Great Game in Central Asia (London: I.B. Tauris, 2000); Rashid, "Central Asian Elites, Suddenly, Shift Into Revolt," Global Affairs Commentary: Foreign Policy in Focus (2 May 2002); Rashid, Jihad: The Rise of Militant Islam in Central Asia (New Haven: Yale University Press, 2002); and Rashid, "Russia, China Warily Watch for American Intrusions in Central Asia," Global Affairs Commentary: Foreign Policy in Focus (3 May 2002). 
it was on Afghan territory that the training camps for fighters in this movement were located. Central Asian countries securitized internal Afghan processes up until 2002, and this was the main reason for those countries to unite among themselves and with such powers as Russia and China. Such a level of interconnection between Central Asian countries and Afghanistan creates the possibility of the emergence of a new insulator zone including Central Asia and Afghanistan, especially if U.S. operations in Afghanistan weaken ties between Afghanistan and Pakistan.

The weakness of inter-regional ties is a driver for the weakness of international organizations as well, such as the Treaty on Collective Security of CIS Countries (1992) and the subsequent Collective Security Treaty Organization (2003), the Shanghai Cooperation Organization (2001), and others. At the same time, these organizations' format demonstrates Central Asia's lack of coherence since, on the one hand, not all Central Asian countries are members of those organizations, and on the other, these organizations include powers from outside the region (Russia, China). ${ }^{23}$

In this way, although the intensity of security dynamics in Central Asia is extremely low compared to the dynamics in surrounding regions (for example, there is much greater securitization of the Kazakhstan-China and Kazakhstan-Russia relationships than exists between Kazakhstan and Kyrgyzstan or Turkmenistan). Nonetheless, the level of interaction with neighboring regional security complexes is high not in absolute terms, but relative to the weakness of cooperation within the region.

\section{The Global Level}

The global level of security dynamics is defined by the interactions with and securitization of global powers, either superpowers (the United States) and/or great powers (China, Japan, Russia, and the EU). As opposed to the case of regional powers, the dynamics of global powers do not play out within a single region. Russia, China and the U.S. exert the greatest influence on Central Asia.

Russia's position is driven by how much it securitizes its desire to form a regional security complex (with Russia at its center) that includes, among others, the countries of Central Asia. Even though Russia is quite thoroughly integrated in the Central Asian security arena, especially in the sphere of military security, such a complex does not presently exist. On one hand, Russia is a weak state, and has no specific national strategy with respect to Central Asia. On the other hand, other external forces' involvement in Central Asia has proved to be less pronounced than was expected in the early 1990s, and has not been a factor prompting Russia to get involved in the mini-complex of the region.

Another factor affecting Russia's Central Asian policy is that Central Asia itself is not a single entity. Only some Central Asian countries — primarily Kazakhstan — can be included in the regional security complex being created around Russia. This is confirmed by the makeup of existing multilateral structures (for instance, the Collective Secu-

23 At present, the members of the Collective Security Treaty Organization are Armenia, Belarus, Kazakhstan, Kyrgyzstan, Russia, and Tajikistan. Members of the Shanghai Cooperation Organization are Kazakhstan, China, Kyrgyzstan, Russia, Tajikistan, and Uzbekistan. 
rity Treaty Organization or the Customs Union). In any case, Russia wishes to retain Central Asia as a stable buffer zone that functions as a natural cordon sanitaire against the proliferation of "new security threats," and to prevent Central Asia from becoming a source of such threats.

The processes of securitization and desecuritization in Russia are being accomplished by various sub-state actors that have varying degrees of influence on national policy. From this standpoint, its impact on the mini-complex creates a space for sub-state and transnational actors to operate whose ties are either along the lines of transnational organized crime (narcotics trafficking), or along financial and industrial lines (aluminum industry, aviation industry, oil and gas, cotton production). That Russia actively securitizes the issue of international terrorism - thus defining to a great extent Russia's ties to the Central Asian states - is of great importance in the context of this study. A major reason for the formation of the Collective Security Treaty Organization and the Shanghai Cooperation Organization was this commonality of approaches to securitizing international terrorism.

In contrast to Russia, China is a quite powerful state; however, for China, too, the domestic, regional, and global levels are more important that the dynamics linking it to Central Asia. In the Central Asian context, China acts in concert with Russia. On the global level, this cooperation is built on the fact that China acknowledges Russian leadership in Central Asia. ${ }^{24}$ Thus far, China regards this as the best strategy to guarantee stability in the Central Asian mini-complex and thus to influence the Uighur rebels in Xinjiang.

That being said, China is gradually strengthening its position in Central Asia as the leading actor in the security and economic spheres. This trend is being formalized by the Shanghai Cooperation Organization, ${ }^{25}$ demonstrating that Russia recognizes that it is unable to single-handedly determine Central Asia's role and place in the world.

The United States dynamic intersects with the security dynamic in Central Asia, primarily at the inter-regional level - through the East Asian and South Asian regional security complexes - as well as the global level, as defined by U.S. interaction with the great powers, Russia and China. It also intersects with such global problems as terrorism, the proliferation of weapons of mass destruction, organized crime, and drug trafficking.

${ }^{24}$ Stephen Blank, "The new Russo-Chinese 'Partnership' and Central Asia," Central Asia and Caucasus Analyst 16 (August 2000), available at: www.cacianalyst.org./Headline1.htm; and Dmitri Trenin, The End of Eurasia (Moscow: Carnegie Moscow Center, 2001), 130, 203.

25 The activities of this entity, known since 1997 as the "Shanghai Five" were directed at resolving border issues between China, Kazakhstan, Kyrgyzstan, and Tajikistan. After Uzbekistan joined in 2001 and the Shanghai Cooperation Organization was actually institutionalized, its sphere of activities expanded and now encompasses both economic and security issues, including the fight against terrorism, the drug trade, fundamentalism, and separatism (see the Shanghai Convention on the Fight Against Terrorism, Separatism and Extremism of 2001). 
The military actions taken by the U.S. in the wake of the September 11 terrorist attacks and the formation of the anti-terrorism coalition led by the United States created special conditions for the emergence of a new debate on international security, in which the fight against international terrorism occupies a central position. Reference in the discourses of all nations to the threat of international terrorism and the fight against it has become legitimate in the international community.

Central Asia has been drawn directly into the fight against international terrorism through Operation Enduring Freedom and due to its proximity to Afghanistan. This has enabled the ruling elites of the Central Asian states to strengthen authoritarian regimes by securitizing international terrorism and making declarations about terrorist groups' activities within their borders. What is important to note is that the emphasis is being placed on the international nature of these groups, since this makes it possible to ignore the domestic causes of terrorism and the conditions in which they emerged. Thus, U.S. policy in Central Asia has brought about a change in security dynamics at the inter-regional and global levels, but it has not had a similar impact at the intrastate and interstate levels. U.S. actions are diminishing the possibility of bringing the inter-regional complex dynamic to bear at the level of the mini-complex, and yet remain insufficient to serve as an alternative source of domination; instead, they work to strengthen the states and power structures in Central Asia. ${ }^{26}$

\section{Conclusion}

Analysis of international terrorism issues according to regional security complex theory makes it possible to identify the following conditions that shape the main ways that problems of international terrorism are formulated and articulated in Central Asian discourse:

- The weakness of Central Asian states and the absence of the basic structures of a regional security complex create the space necessary for non-state actors to operate.

- The authoritarian nature of Central Asian regimes promotes the securitization of the fight against international terrorism in order to justify limiting political and economic freedoms, strengthening power structures, and maintaining existing regimes.

- The international community's acceptance of a discourse in which the central theme is the fight against international terrorism, and the nature of the international organizations currently arrayed around Central Asia, driven by the activities of the great powers, create conditions that encourage securitization of the fight against international terrorism.

${ }^{26}$ S. Frederick Starr, "The War Against Terrorism and U.S. Bilateral Relations with Central Asia," Testimony to the U.S. Senate, Committee on Foreign Relations, Subcommittee on Central Asia and the Southern Caucasus, 13 December 2001, available at: http://www.cacianalyst.org/Publications/Starr_Testimony.htm. 
Speaking of the main characteristics of the discourse that is currently taking shape in Central Asia (in the context of this article), it may be noted that this discourse assumes international terrorism as its subject, while at the same time it inhibits the possibility of stating and defining the domestic causes of terrorist acts directed against existing political regimes. The extremist actions that manifest themselves periodically, driven by latent tensions in society, are interpreted by the ruling elites as acts of international terrorism. A discourse in which a central position is occupied by the fight against international terrorism also stands in the way of a clear determination of the issues of human rights and civil liberties. 


\section{Bibliography}

Blank, Stephen. "The new Russo-Chinese 'Partnership' and Central Asia." Central Asia and Caucasus Analyst 16 (2000).

Burnashev, Rustam. "Regional Security in Central Asia: Military Aspects." In Central Asia: A Gathering Storm. New York: M. E. Sharpe, 2002.

Buzan, Barry, and Ole Wæver. Regions and Powers: The Structure of International Security. Cambridge: Cambridge University Press, 2004.

Buzan, Barry, Jaap de Wilde, and Ole Waeve. Security: A New Framework for Analysis. Boulder, Colorado: Lynne Rienner Publishers, 1998.

Coppieters, Bruno. "The Partnership for Peace with Central Asia." In Ethnic and Regional Conflicts in Eurasia. Vol. 3., 1997.

Der Derian, James. Antidiplomacy: Spies, Terror, Speed, and War. Oxford: Blackwell Publishers, 1992.

Peimani, Hooman. Regional Security and the Future of Central Asia. Westport, CT: Praeger, 1998.

S. Starr, Frederick. The War Against Terrorism and U.S. Bilateral Relations with Central Asia. U.S. Senate, Committee on Foreign Relations, Subcommittee on Central Asia and the Southern Caucasus, 2001.

Trenin, Dmitri. The End of Eurasia . Moscow: Carnegie Moscow Center, 2001. 